\title{
ROLE OF DEBRIS COVER IN THE THERMAL PHYSICS OF GLACIERS
}

\author{
By A. N. BOZHINSKIY, \\ (Laboratory of Snow Avalanches and Mudflows, Geographical Faculty, Moscow State University, Moscow \\ 117234, U.S.S.R.)
}

M. S. KRASS,

(Institute of Mechanics, Moscow State University, Moscow 117234, U.S.S.R.)

and V. V. POPOVNIN

(Laboratory of Snow Avalanches and Mudflows, Geographical Faculty, Moscow State University, Moscow

117234, U.S.S.R.)

ABSTRACT. A mathematical model is presented of nonstationary melting processes of ice including particles of morainic material. The problem is treated as a Stephen-type one with the phase boundary of ice melting being located under the debris cover. The main terms of the heat-balance equation for a glacier surface are solar radiation and convective heat transfer. The quantitative relationships characterizing the effect of glacier run-off augmentation from under a thin layer of debris cover are obtained for different bulk moraine concentrations inside the ice. The concept of equivalent time is introduced. It is defined as the time elapsed until the moment the sub-moraine iceablation rate becomes equal to the ablation rate of clean ice. This moment signifies the beginning of the shielding stage. Thus, a glacier can be considered as a self-controlling system with respect to its summer run-off. A series of numerical tests for Djankuat glacier, Central Caucasus, has been carried out. The dynamics of moraine-cover growth and alterations of seasonal ablation rate under debris show perfect agreement between the computed data and the results of 14 years of direct observations. Some practical recommendations concerning artificial blackening of a glacier surface for augmentation of liquid run-off are presented. Conditions promoting increase of run-off are: relatively high albedo, relatively low summer air temperature, and relatively small convective heat transfer between the air and the ice surface. The method of artificially blackening a glacier surface is by means of a durable thin dark polymer film. In conclusion, some further aspects of the problem are discussed.

RÉsumé. Rôle de la couverture de débris dans la physique thermique des glaciers. On présente un modèle mathématique sur les processus non stationnaires de fonte de glace en présence de matériel morainique. Le problème est du type Stéphan avec une frontière de fonte de glace situé à la base d'une couche de débris. Les termes principaux de l'équation du bilan de chaleur à la surface sont dus à la radiation solaire et au transfert convectif. Les relations quantitatives caractéristiques de l'effet d'augmentation de débit dû aux fines couches de débris de surface sont obtenues pour différentes concentrations morainiques internes à la glace. On introduit le concept de temps équivalent, définit comme étant le temps passé jusqu'au moment où l'ablation de glace sous la couche de moraine devient égal à celle d'une glace propre. Ce moment est le début du stade de protection. Dans ces conditions un glacier peut être considéré comme un système se contrôlant lui même par rapport à son écoulement hydraulique estival. Une série de tests numériques ont été effectués pour le glacier Djankuat, Caucase central. La dynamique de croissance de la couverture morainique et les modifications de l'ablation saisonnières sous la couche de débris montrent une parfaite concordance entre les résultats du calcul et les 14 années d'observations directes. On fournit quelques recommandations pratiques sur le noircissement artificiel de surface glaciaires en vue d'augmenter le débit d'eau. Ces conditions à réunir pour favoriser cet accroissement de débit sont: un albedo relativement fort, une température estivale relativement basse et un transfert convectif de chaleur relativement faible entre l'air et la surface de glace. La méthode de noircissement artificiel de la surface du glacier utilise un fin film sombre de polymère. En conclusion, d'autres aspects de ce probléme sont discutés.

ZUSAMMENFASSUNG. Die Rolle der Schuttdecke im thermischen Verhalten von Gletschern. Es wird ein mathematisches Modell für das nicht-stationäre Problem des Schmelzprozesses von Eis, das Moränenmaterial enthält, vorgelegt. Das Problem wird als eines vom Stephan-Typ behandelt, wobei die Phasengrenze schmelzenden Eises unter der Schuttdecke liegt. Die Hauptglieder der Wärmebilanzgleichung für die Gletscheroberfläche sind die Sonnenstrahlung und der konvektive Wärmetransport. Die quantitativen Beziehungen zur Charakterisierung der Wirkung der Zunahme des Gletscherabflusses aus der Zone unter einer dünnen Schicht von Deckschutt werden für verschiedene Konzentrationen von Morănenmaterial im Eis gewonnen. Das Konzept der åquivalenten Zeit wird eingeführt. Sie ist definiert als Zeitspanne bis zu dem Augenblick, wo die Ablationsrate des schuttbedeckten Eises gleich der des reinen Eises wird. Dieser Augenblick kennzeichnet den Beginn des Abschirmzustandes. Ein Gletscher kann so im Hinblick auf seinen sommerlichen Abfluss als ein sich selbst regulierendes System betrachtet werden. Eine Reihe von numerischen Tests wurde für den Djankuat-Gletscher im Zentral-Kaukasus angestellt. Hinsichtlich der Dynamik der Zunahme der Schuttdecke und der Veränderungen der jahreszeitlichen Ablationsrate unter dem Schutt zeigen eine vollständige Übereinstimmung zwischen den berechneten Werten und den Ergebnissen 14-jähriger direkter Beobachtungen. Für die künstliche Schwärzung der Gletscheroberfläche zur Vermehrung des Abflusses werden einige praktische Empfehlungen gegeben. Bedingungen für eine solche Zunahme: relativ hohe Albedo, relativ niedrige Luftemperatur im Sommer und relativ geringer konvektiver Wărmetransport zwischen Luft und Eisoberfläche. Die Methode der künstlichen Schwärzung von Gletscheroberflächen benützt einen dauerhaften, dünnen, dunkeln Kunststoffilm. Abschliessend werden einige neue Aspekte des Problems diskutiert. 
INTRODUCTION - HISTORY AND ESSENCE OF THE PROBLEM

The problem of the surface thawing of glaciers covered with moraine has been discussed in a number of papers (e.g. Avsyuk, 1953; Kreiter and Tikhanovskaya, 1964; Tronov, 1966; Dolgushin and others, 1972; Khodakov, 1972[a], [b]; Konovalov, 1979). Correct understanding and description of the physical processes accompanying heat and mass exchange on a glacier surface will permit estimations of alterations to its thermal regime and run-off to be made either under conditions of natural moraine cover or when the surface is blackened by external processes, such as glacier soiling by tephra material after volcanic eruptions and anthropogenic influences.

The main qualitative results of the works mentioned above are as follows. When the thickness of moraine cover is small, of the order of several centimetres, the rate of ice thawing increases. This effect was discovered experimentally (Østrem, 1959) by artificially covering a representative area on a glacier surface with dust. This effect also takes place with snow (Higuchi and Nagoshi, 1977). Use of a rather simple model shows (Zotikov, 1982) that the increase of the thawing rate is related to changes (an exponential decrease during the melting season) in the surface albedo of ice covered by a thin layer of dust. However, moderate thicknesses of moraine cover result in a shielding (armouring) effect; the ice thawing rate decreases and when the thickness of moraine reaches about $1.5-2 \mathrm{~m}$ melting practically ceases (Dolgushin and others, 1972). Experimental data obtained from glaciers in the Caucasus and in Central Asia, which have been summarized by Khodakov (1972[a]) and Dolgushin and others (1972), show a hyperbolic dependence between the thawing rate decrease and moraine-cover thickness. A theoretical basis for this relationship was given by Khodakov (1972[a]), who obtained an approximate solution for the stationary heat conduction equation within the moraine layer. More recently, some theoretical attempts have been made to construct the curve describing the variation in ice thawing rate over a wide range of moraine thicknesses. This has been done by using a quasi-stationary model of the interaction between solid, liquid, and gaseous phases (Denisov, 1980), and also by proceeding from purely geometric considerations concerning the shape of the curve (Konovalov, 1979). Khodakov (1972[b]) also gave an approximate description of the non-steady problem.

A complete theoretical treatment of the non-steady thawing of ice containing particles of morainic material does not yet exist. This paper gives such a treatment and applies the model to Djankuat glacier, a high-alpine valley glacier of the Central Caucasus. In addition, quantitative relationships characterizing the effect of the most intensive glacial thawing under debris cover are obtained. Thoughts about the advisability of employing this effect for the artificial adjustment of summer glacier run-off in different regions are given and some practical recommendations are also presented.

\section{ON THE FORMATION OF MORAINE COVER}

Superficial moraines on mountain glaciers form as a result of three processes: the deposition of colluvial material on the glacier surface, the melting-out of englacial moraine, and the widespread development of thrust moraines (transfer of debris from the glacier bed to the surface along shear planes). The formation of medial moraine is a particular case of the first or second formation mechanism depending on whether the convergence point of glacier tributaries is above or below the firn line.

Moraine cover, i.e. a form on a glacier where concentrations of debris do not manifest themselves as strongly pronounced lengthwise relief features but cover the snout surface by a continuous lithogenic envelope, may arise as a result of any of the three mechanisms mentioned above.

The most frequent type of continuous moraine-cover formation is caused by the confluence of a number of medial moraines or the junction of medial moraines with lateral ones. Both of these types of moraines are usually well pronounced in glacial relief as longitudinal ramparts.
However, proximity to a glacier terminus and slow ice-flow velocities induce the sprawling of moraine ramparts; in their axial parts, where debris thickness is greatest, one can observe the near cessation of ice thawing. However, as adjacent areas of clean ice lower progressively and the steepness of lateral slopes and the relative height of the rampart increases, lithogenic material undergoes gravitational re-distribution. Debris accumulates along the foot of the rampart, so that the flank steepness tends to its angle of natural repose. The strips of clean ice between adjacent ramparts gradually taper off and sometimes completely pinch out. The closer the ramparts, the sooner this pinching out occurs, and this is therefore especially characteristic of large glaciers with a complicated structure in their upper reaches and with long and narrow snouts. Afterwards, the relief vanishes, since morainic material accumulating between the ramparts creates an armouring envelope while debris slipping down the flanks of the ramparts periodically exposes the substrate ice, which resumes its melting. Thus, the superficial moraine plays the role of a self-developing system tending towards the minimization of relief, and the transformation of linear features into a continuous debris envelope.

Of course, explaining the formation of moraine cover solely as a result of the confluence of several medial moraines is too simplistic. On some glaciers, a significant role is played by ablation moraine, and a continuous cover arises from the areal melting-out of debris dispersed randomly inside a glacier body. However, the existence of a continuous moraine cover seems to be a characteristic feature of the retreating phase of large glaciers and essentially governs mass and heat transfers in their lower reaches.

The processes of debris thawing out from glacier ice is described below. For simplicity, the composition of the moraine cover is supposed to be homogeneous.

\section{FORMULATION OF THE PROBLEM}

The mathematical problem of moraine thawing out of debris-containing ice is now formulated.

Let $\mu$ be the bulk debris concentration in the uniform ice debris. Attention is confined to the one-dimensional case neglecting horizontal effects. Such a schematization is applicable provided the horizontal dimension of the object is much greater than the vertical one, i.e. the moraine layer is relatively thin. The coordinate $z$ is directed downwards (Fig. $1)$, the origin being coincident with the initial surface of the debris-containing ice layer. After thawing out, the debris-bearing layer has a thickness

$$
h(t)=\frac{\mu}{1-p} \xi(t), \quad \mu=\text { const },
$$

where $z=\xi(t)$ is the position of the phase boundary of ice melting, $p$ is the porosity of the debris cover, and $t$ is the elapsed time. The process of debris consolidation is not examined here; the moraine is assumed to remain homogeneous in time and therefore the porosity is constant. Melt water is also assumed to leave the moraine layer practically instantaneously. The latter assumption can be justified for two reasons: first, the process of thawing out is too prolonged for melt water to trickle down the glacier slope; secondly, natural observations show that the debris layer throughout its thickness does not contain free water, except as a thin film at the contact with the ice. The moraine and the ice-moraine are assumed to be devoid of heat sources.

The temperature $T_{\mathrm{m}}$ within the moraine layer is governed by the heat-transfer equation

$C_{\mathrm{m}} \rho_{\mathrm{m}} \frac{\partial T_{\mathrm{m}}}{\partial t}=\lambda_{\mathrm{m}} \frac{\partial^{2} T_{\mathrm{m}}}{\partial z^{2}},\left(1-\frac{\mu}{1-p}\right) \xi(t)<z<\xi(t)$.

Here, $C_{\mathrm{m}}, \rho_{\mathrm{m}}$, and $\lambda_{\mathrm{m}}$ denote the specific heat, density, and heat conductivity of the debris cover, respectively, and $t$ is time. 
$Z=0$

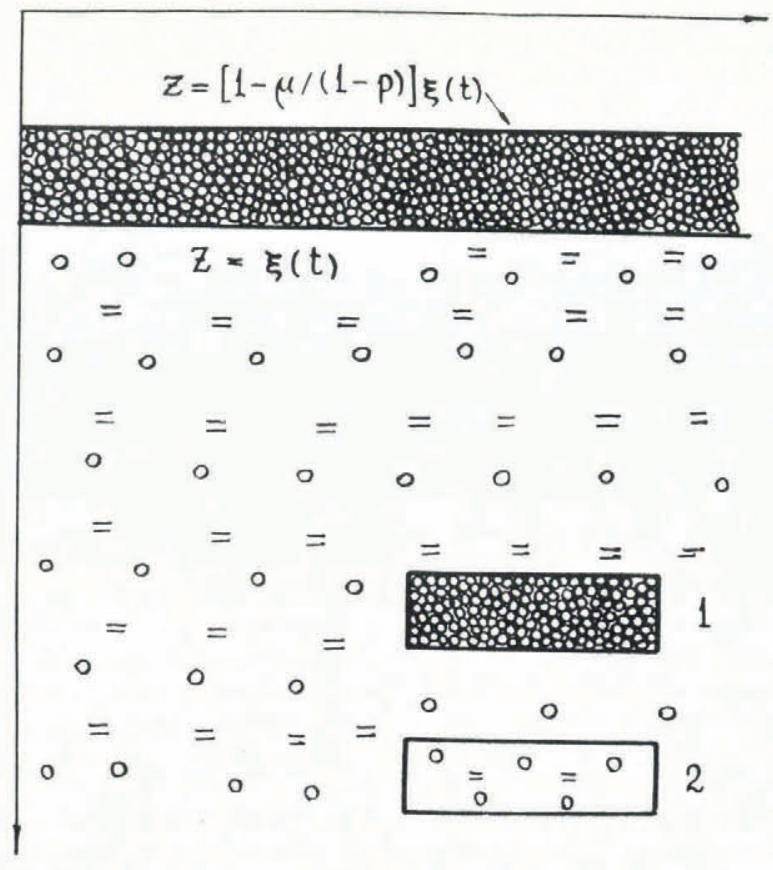
Fig. 1. The coordinate system for the problem. 1, moraine;
2, ice.

The temperature $T$ of the debris-containing ice is also determined by the heat-transfer equation

$$
C \rho \frac{\partial T}{\partial t}=\lambda \frac{\partial^{2} T}{\partial z^{2}}, \quad \xi(t)<z<\infty .
$$

Thermophysical parameters in Equations (2) and (3) can be estimated from the volume-weighted averages of the corresponding constituent parameters, i.e.

$$
\begin{aligned}
& C=C_{\mathrm{i}}(1-\mu)+C_{\mathrm{g}} \mu, \rho=\rho_{\mathrm{i}}(1-\mu)+\rho_{\mathrm{g}} \mu, \\
& \lambda=\lambda_{\mathrm{i}}(1-\mu)+\lambda_{\mathrm{g}} \mu ; \\
& C_{\mathrm{m}}=C_{\mathrm{g}}(1-p)+C_{\mathrm{a}} p, \rho_{\mathrm{m}}=\rho_{\mathrm{g}}(1-p)+\rho_{\mathrm{a}} p, \\
& \lambda_{\mathrm{m}}=\lambda_{\mathrm{g}}(1-p)+\lambda_{\mathrm{a}} p
\end{aligned}
$$

where symbols with subscripts i correspond to pure ice, $g$ to debris material, and a to air.

We now define the boundary conditions for the problem. On the upper boundary of the moraine cover the heat flux can be set as

$$
z=\left[1-\frac{\mu}{1-p}\right] \xi(t),-\lambda_{\mathrm{m}} \frac{\partial T_{\mathrm{m}}}{\partial z}=q_{1}+q_{2}+q_{3}+q_{4}(5)
$$

where $q_{j}(j=1-4)$ are heat fluxes caused by solar radiation, evaporation/condensation, radiation from the surface and convective heat exchange with the air, respectively. More detailed estimates of these terms are given below.

The lower boundary of the moraine $z=\xi(t)$ represents a phase boundary. Two conditions are set on this boundary: the temperature at ice melting-point $T_{\mathrm{h}}$ and a condition that defines the movement of the boundary itself (Tikhonoy and Samarskiy, 1972)

$z=\xi(t), T_{\mathrm{m}}=T=T_{\mathrm{h}},\left[-\lambda \frac{\partial T}{\partial z}\right]=Q \rho_{\mathrm{i}}(1-\mu) \frac{\mathrm{d} \xi}{\mathrm{d} t}$

where $Q$ is the latent heat for the phase transition and the square brackets signify the jump in heat flux at the phase boundary. Equation (6) shows that the rate of movement of the phase boundary in debris-containing ice depends only on the difference between the heat fluxes across the interface.

The layer of debris-containing ice is assumed to be infinitely thick, and so the condition

$$
z \rightarrow \infty, T=T_{\mathrm{i}} \lesssim T_{\mathrm{h}}
$$

is set.

Since the thermal problem is evolutional, the initial state has to be fixed. Let us assume that initially the moraine layer is absent, i.e. the whole area $z \geqslant 0$ corresponds to the uniform mixture of debris and ice with constant temperature

$$
t=0 ; \xi=0, T=T_{\mathrm{i}} ; z=0,-\lambda \frac{\partial T}{\partial z}=q_{1}+q_{2}+q_{3}+q_{4} .
$$

The third condition in Equations (8) requires that the initial heat flux on the free surface of debris-containing ice be given.

Equations (1)-(8) completely define the mathematical problem of debris thawing out of ice. This problem is nonlinear by virtue of the second condition in Equations (6) Its solution also permits the determination of the ablation rate immediately beneath the moraine; from Equations (6) it can be found to be

$a_{\mathrm{m}}(t)=(1-\mu) \frac{\mathrm{d} \xi}{\mathrm{d} t}=\frac{1}{\rho_{\mathrm{i}} Q}\left[-\lambda \frac{\partial T}{\partial z}\right]_{z}=\xi(t)$.

In the particular case when $T_{\mathrm{i}}=T_{\mathrm{h}}=0^{\circ} \mathrm{C}$ (debriscontaining ice is at its melting point), the formula cited by Khodakov (1972[b])

$$
a_{\mathrm{m}}(t)=-\frac{\lambda_{\mathrm{m}}}{\rho_{\mathrm{i}} Q} \frac{\partial T_{\mathrm{m}}}{\partial z} \quad z=\xi(t)
$$

can be obtained from Equation (9).

This formulation of the equations governing the thawing out of debris from ice and its concentration on the surface can be extended by altering Equation (1) to take into account the mass influx of debris material from outside or its outflow as a result of slipping:

$$
h^{\prime}=h_{\text {int }}+h_{\text {ext }}
$$

where $h_{\text {int }}$ is defined by Equation (1) and the function $h_{\text {ext }}$ represents external sources of debris.

Before proceeding further, it is necessary to consider in more detail the heat transfer at the free surface. We estimate the orders of all the terms on the right-hand side of Equations (5) and (8); to that purpose we deduce formulae for each summand.

The heat influx to the surface due to solar radiation is defined by

$$
q_{1}=Q_{\mathrm{s}}\left(1-\alpha_{\mathrm{m}}\right) .
$$

Here, $Q_{\mathrm{S}}$ is the total radiation flux (direct plus scattered solar radiation) and $\alpha_{m}$ is the moraine albedo. As a rule, in a high mountain belt, $Q_{S}$ reaches a value of about $120 \mathrm{~W} \mathrm{~m}^{-2}$.

The remaining terms are evaluated relative to $q_{1}$. The heat flux caused by evaporation and condensation, $q_{2}$, comprises a relatively small part of the total radiation flux, no more than 10\% (Kotlyakov, 1968; Lebedeva, 1972), and therefore this term is disregarded in Equation (5).

The heat flux caused by radiation from the surface, $q_{3}$, is determined by the following expression on the basis of heat-transfer theory (Mikheyev and Mikheyeva, 1977):

$$
q_{3}=\epsilon \sigma_{0}\left(T_{\mathrm{a}}^{4}-T_{\mathrm{m}}^{4}\right)
$$


in which $T_{\mathrm{a}}$ is the air temperature measured here in degrees absolute (as is $T_{\mathrm{m}}$ ); $\sigma_{\mathrm{o}}$ is the emission coefficient of an absolutely black body which equals $5.67 \times 10^{-8}$ $\mathrm{W} \mathrm{m} \mathrm{m}^{-2} \mathrm{~K}^{-4} ; \epsilon$ is the reduced degree of blackness of the system "gas-solid boundary" that is defined in thermal physics as

$$
\epsilon=\frac{\epsilon_{\mathrm{a}} \epsilon_{\mathrm{m}}}{\epsilon_{\mathrm{m}}+\epsilon_{\mathrm{a}}\left(1-\epsilon_{\mathrm{m}}\right)}
$$

where $\epsilon_{\mathrm{a}}$ and $\epsilon_{\mathrm{m}}$ are the degrees of blackness of gas and boundary correspondingly. The degree of blackness characterizes the total or integral emission of a body embracing all wavelengths: $0 \leqslant \epsilon \leqslant 1$ ( 1 is the degree of blackness for an absolutely black body) (Mikheyev and Mikheyeva, 1977). For solid non-granular materials, the degree of blackness is usually $\epsilon_{m} \approx 0.5-0.6$; for the air, $\epsilon_{\mathrm{a}}$ depends on the spectral degrees of blackness of its components and for usual temperatures does not exceed 0.1, subject to water-vapour content. Consequently, from Equation (13), the reduced degree of blackness

$$
\epsilon \approx 0.05 \text {. }
$$

Since the difference between air and moraine temperatures does not exceed $20 \mathrm{deg}$, the term in Equation (12), using these parameter values, is only a few per cent of $q_{1}$. Hence heat flux caused by radiation is negligible when temperatures are low.

The last term in condition (5) describes the convective heat exchange at the system gas-boundary interface. Heat flux is represented by

$$
q_{4}=b\left(T_{\mathrm{a}}-T_{\mathrm{m}}\right),
$$

where $b$ is the eddy-heat emission factor defined as (Mikheyev and Mikheyeva, 1977)

$$
b=\frac{\mathrm{Nu} \cdot \lambda_{\mathrm{a}}}{l}
$$

In Equation (15) $\mathrm{Nu}$ signifies the Nusselt number, which defines the intensity of convective heat exchange between the body surface and the gas stream; $\lambda_{a}$ is the heat conductivity of the gas; and $l$ is the characteristic size of the surface the gas is flowing past. When the gas flow past the solid surface is turbulent, the Nusselt number is defined as (Mikheyev and Mikheyeva, 1977):

$$
\mathrm{Nu}=0.032 \mathrm{Re}^{0.8} .
$$

Here, $\mathrm{Re}$ is the Reynolds number which depends on the characteristic gas velocity $w$, the characteristic size $l$, and the kinematic viscosity of the gas $v$ (Mikheyev and Mikheyeva, 1977)

$$
\operatorname{Re}=\frac{w l}{v}
$$

Taking an average wind velocity over the glacier surface, $w=5 \mathrm{~m} / \mathrm{s}$, the characteristic size of the moraine surface $l \geqslant 100 \mathrm{~m}$, and assuming that at a temperature of about $10-20^{\circ} \mathrm{C}$ the heat conductivity, $\lambda_{a}$, is equal to $0.024 \mathrm{~W} \mathrm{~m}^{-1}$ $\mathrm{deg}^{-1}$, and its kinematic viscosity $v=1.5 \times 10^{-7} \|^{2} / \mathrm{s}$ (Vagaftik, 1963), one can obtain from Equations (15)-(17) that

$$
b \approx 12 \mathrm{~W} \mathrm{~m}^{-2} \mathrm{deg}^{-1}
$$

When $\left|T_{\mathrm{a}}-T_{\mathrm{m}}\right| \approx 10-20 \mathrm{deg}$, the term in Equation (14) has the same order of magnitude as the first term in Equation (11), as in Equation (5).

Thus, retaining the dominant terms in Equation (5) leads to the relationship:

$$
\begin{aligned}
z & =\left(1-\frac{\mu}{1-p}\right) \xi(t), \\
& -\lambda_{\mathrm{m}} \frac{\partial T_{\mathrm{m}}}{\partial z}=Q_{\mathrm{s}}\left(1-\alpha_{\mathrm{m}}\right)+b\left(T_{\mathrm{a}}-\mathrm{T}_{\mathrm{m}}\right)
\end{aligned}
$$

It should be noted that a similar expression is cited in Khodakov (1972[a]) for the approximate computation of heat flow through a moraine surface, but Khodakov's formulation uses too many undetermined parameters to be useful.

The initial condition in Equation (8) is simplified in the same way:

$$
\begin{aligned}
& t=0 ; \quad \xi=0, \quad z=0,- \\
& --\lambda \frac{\partial T}{\partial z}=Q_{\mathrm{S}}\left(\begin{array}{ll}
1 & \alpha
\end{array}\right)+b\left(T_{\mathrm{a}}-T\right) .
\end{aligned}
$$

$\alpha$ here denotes the debris-containing ice albedo, i.e. initially the heat flux on the free surface is defined by thermophysical parameters of the initial mixture of ice and moraine; after the appearance of the first elementary debris layer $(\xi(t)>0)$, heat flux on the free surface is also affected by the moraine properties. In reality, such an abrupt jump could not occur because the surface albedo changes gradually from the value $\alpha$ representative of debriscontaining ice to the value $\alpha_{\mathrm{m}}$ representative of moraine cover. Field observations indicate that the albedo of debriscontaining ice decreases with the increase in the concentration of lithogenic matter. The dependence of the glacier-surface albedo on the weight content of fine-grained matter and on the fractional coverage by spheroidal particles has been investigated by Tikhanovskaya (1970[b]) and Zotikov (1982), respectively. It would appear that the albedo of a surface with a moraine cover can be defined as a function of cover thickness $h$ including in it dependence on debris concentration and also on the degree of blackness by the following relationship:

$$
\alpha_{\mathrm{m}}=\alpha_{\mathrm{g}}+\left(\alpha-\alpha_{\mathrm{g}}\right) \mathrm{e}^{-\gamma h} .
$$

Here, $\boldsymbol{y}$ is the albedo decrement which has to be determined empirically and $\alpha_{\mathrm{g}}$ is the albedo of morainic material. The dependence of $\alpha_{\mathrm{m}}$ on debris-layer thickness $h$ is shown in Figure 2.

Consequently, the initial condition in Equation (20) that defines heat exchange on the surface, with Equation (21) taken into account, enters into the condition in Equation (19); similarly, $\lambda_{\mathrm{m}}$ should be expressed in a form similar to Equation (21):

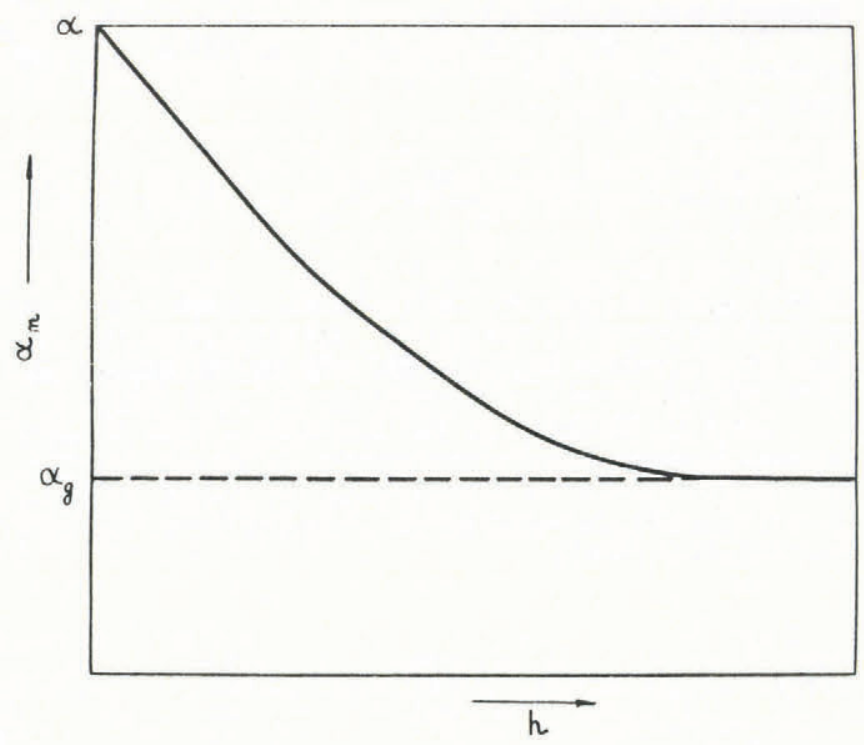

Fig. 2. Surface-albedo dependence on moraine-cover thickness. 


$$
\lambda_{m}=\lambda_{m}^{\prime}+\left(\lambda-\lambda_{m}^{\prime}\right) \mathrm{e}^{-\gamma h}
$$

where the prime corresponds to the moraine layer. This equation is supposed to exclude the jump in the thermal diffusivity in Equation (19). The exponential coefficient $\gamma$ in Equations (21) and (22) is the same for simplicity.

The initial condition can now be simplified to the following expressions:

$$
t=0 ; \quad h=\xi=0 ; \quad T=T_{\mathrm{i}}=\text { const. }
$$

Hence, the final formulation of the problem of thawing-out of moraine-bearing ice comes to a Stephan-type non-linear problem consisting of Equations (2) and (3) with defining expressions in Equations (1) or (1a), (4), (21), and (22), boundary conditions in Equations (6), (7), and (19), and the initial condition in Equation (8a). The eddy heattransfer coefficient is determined with the help of formulae (15) $-(17)$ that give the opportunity to take temporal changes into consideration if the necessary meteorological data are available.

The proposed system of equations and expressions is closed and represents a one-dimensional mathematical model describing the process of thawing-out of moraine-bearing glacier ice and debris-cover formation on its surface.

\section{DJANKUAT GLACIER AND DERIVED PARAMETERS OF ITS DEBRIS COVER}

The non-steady mathematical model of debris-cover formation was applied using numerical techniques to the valley glacier of Djankuat (Dzhankuat).

This glacier is one of the best explored mountain glaciers in the U.S.S.R. Glaciological investigations began here in 1965 and have continued uninterrupted from 1968 up to the present. Djankuat glacier was chosen as a representative I.H.D. basin for the Central Caucasus. Besides the glaciological observations, a vast complex of hydrological, meteorological, geophysical, and other kinds of research was also established there with the main purpose of determining the mass, liquid, and heat balances. The raw factual data obtained here are sufficient to evaluate all input parameters to the model.

Djankuat glacier (Fig. 3) is situated on the northern slope of the Great Caucasus central section. It occupies an area of $3.2 \mathrm{~km}^{2}$ and flows north-west from the main Caucasus Range; its length is $3 \mathrm{~km}$ (Boyarskiy, 1978). The subglacial bed of Djankuat glacier is complicated by rock ledges that give its longitudinal profile a stepped character. Because they are subjected to erosion, these ledges serve as a principal source of subglacial moraine. The glacier flow can be divided into three main branches with independent catchments. The contact zone between adjacent tributaries is marked by medial moraine ramparts. The left-hand margin of the snout in particular is covered by a continuous envelope of debris on the final kilometre of its length.

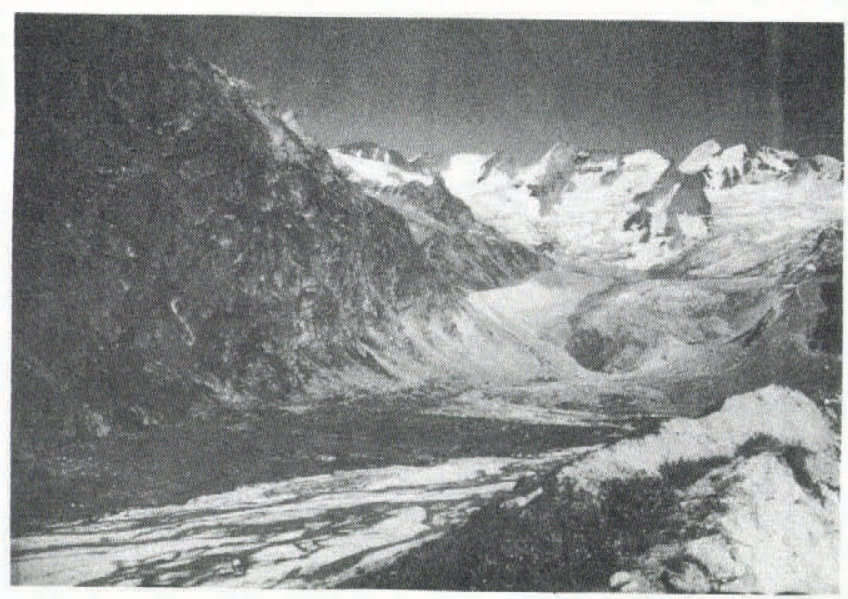

Fig. 3. Djankuat glacier. (Photograph by E.A. Zolotaryov.)
At present, Djankuat glacier, like the majority of Caucasian glaciers, is retreating but the rate of retreat has been decreasing slightly in the last decade. Growing piles of debris on the snout surface can be seen, as is typical of the retreat phase. The total area occupied by the debris cover increased from $0.10 \mathrm{~km}^{2}$ in 1968 to $0.22 \mathrm{~km}^{2}$ in 1983 . The appreciable fraction $(6.9 \%)$ of superficial moraine over the total glacier area, as well as a number of special investigations undertaken in 1982-83, led to the choice of Djankuat glacier as a convenient natural object for validation of the mathematical model.

As was shown in the previous section, solution of the equations that determine the influence of debris cover on heat exchange near the glacier surface requires the determination of a large number of parameters.

\section{Surface albedo, $\alpha$}

Judging from albedo surveys held over all the debriscovered part of Djankuat glacier, albedo values vary greatly. Characteristic values of glacier-surface albedo for different fractional coverage by morainic matter are summarized in Table I. The lowest value for the clean-ice albedo (about 0.35 ) that can be used as the initial albedo before the

\section{TABLE I. CHARACTERISTIC ALBEDO VALUES FOR DIFFERENT SURFACE TYPES OF THE GLACIER}

\section{Surface type}

Albedo

Clean ice

Slightly soiled ice (area of debris is much less than that of ice)

Moderately soiled ice (areas are comparable)

Soiled ice (debris area predominates)

Continuous debris cover

$0.15-0.20$

$0.05-0.14$

commencement of debris thawing out on to the surface appears to be applicable to the modelling.

\section{Rock density, $\rho_{\mathrm{g}}$}

The rock ${ }^{\circ}$ over which Djankuat glacier flows is composed mainly of pre-Cambrian granites and gneissose granites. Their average density can be assumed to be $2.6 \mathrm{Mg} \mathrm{m}^{-3}$ (Birch and others, 1942; Izdatel'stvo Nedra, 1976).

\section{Heat conductivity of the rock, $\lambda_{\mathrm{g}}$}

Heat conductivity of different kinds of granites varies within $\pm 15 \%$ according to regional differences. Values of $\lambda_{g}$ also decrease with increasing temperature, and for gneissose granites the range of $\lambda_{g}$ values is affected by the anisotropy introduced by the planes of schistosity; thus, only those granites were considered whose $\lambda_{\mathrm{g}}$ values at $T=0^{\circ} \mathrm{C}$ lie within the range 2.4 to $2.9 \mathrm{~W} \mathrm{~m}^{1} \mathrm{deg}^{-1}$ (Birch and others, 1942). We used $2.8 \mathrm{~W} \mathrm{~m}^{-1} \mathrm{deg}^{-1}$ in our model.

\section{Specific heat of the rock, $C_{\mathrm{g}}$}

This parameter is also affected by regional distinctions arising as a result of variable mineral composition (Birch and others, 1942). We used $C_{\mathrm{g}}=1.26 \mathrm{~kJ} \mathrm{~kg}^{-1} \mathrm{deg}^{-1}$ in our calculations as this value corresponds approximately to the granite type with the $\lambda_{g}$ value used above.

Packing density, $\hat{\rho}$, and porosity, $p$, of the debris cover

Three possible types of packing of porous materials composed of contacting spheres with the same diameter exist: face-centred cubic, cubic, and rhombohedral. Facecentred cubic packing is the loosest; its density is equal to

$$
\hat{\rho}=\frac{3^{\frac{1}{2}}}{16} \pi \approx 0.34
$$

Cubic packing is more dense:

$$
\hat{\rho}=\frac{\pi}{6} \approx 0.52 \text {. }
$$


Rhombohedral, the densest packing, with a density of about 0.74 , is purely theoretical since it can never be realized either in Nature or in experiment. Therefore, the most likely $\hat{\rho}$ value is expected to lie in the range $0.55-0.60$.

The porosity is defined as

$$
p=1-\hat{\rho}
$$

and consequently a characteristic value here would lie in the range $0.40-0.45$.

The porosity is necessary for the correct calculation of the physical and thermophysical properties of the moraine cover treated as an aggregate from the corresponding indices of the moraine-cover constituents. Strictly speaking, the debris cover is a three-component medium, a mixture of rocks, water, and air. In order to avoid unnecessary complication, the medium is considered here to be one-component and to possess the mean thermophysical properties defined by formulae similar to Equation (4).

\section{Concentration, $\mu$, of debris in ice}

This parameter is the most difficult to estimate as it is not amenable to direct measurement. In order to obtain numerical values of $\mu$, the moraine distribution over the snout in 1968 was compared with the results of a moraine survey done in the summer of 1983. For this purpose, the displacement of the snout surface using previously measured surface-velocity values (Boyarskiy, 1978) was also taken into account. In the central stream of the left branch of the snout, a representative sector with an area of $0.028 \mathrm{~km}^{2}$ was selected. In 1968, this area was devoid of surface moraine, whereas today it is completely covered by debris. For the calculation of the mean moraine thickness $\bar{h}$, values of $h$ at 85 nodes of the normal square net were found to have an average value of $13 \mathrm{~cm}$. The volume of the accumulated debris $\left(2.07 \times 10^{3} \mathrm{~m}^{3}\right.$, using the representative porosity value $p=0.43$ ) was combined with the total summer ablation of this area obtained from direct glaciological measurements over a 14 year time span $\left(5.50 \times 10^{4} \mathrm{~mm}\right.$ water equivalent, or $1.75 \times 10^{6} \mathrm{~m}^{3}$ of glacier ice using a density $\rho_{\mathrm{i}}=880 \mathrm{~kg} \mathrm{~m}^{-3}$ ). The resulting debris mass concentration inside the glacier was approximately $0.12 \%$.

Values of $\mu$ obtained by this method will be underestimated if the moraine conditions are compared for dates separated from each other by long periods during which the moraine cover has enough time to reach a sufficiently great thickness (for example, in the representative area it reached $38-43 \mathrm{~cm}$ at some points) such that it screens the subjacent ice, so reducing debris flux on to the surface in zones of positive anomalies of $h$. The best estimates of $\mu$ obtained on the basis of moraine-accumulation dynamics should use time spans of no more than a few years.

\section{Air temperature, $T_{\mathrm{a}}$}

Mean monthly air temperatures at the snout of Djankuat glacier are listed in Table II. Usually, direct regular meteorological observations on the glacier cover only

TABLE II. ANNUAL COURSE OF AVERAGE MONTHLY AIR TEMPERATURES AND TOTAL SOLAR RADIATION OVER THE SNOUT OF DJANKUAT GLACIER

$\begin{array}{lrc}\text { Month } & \begin{array}{c}\text { Air temperature } \\ T_{\mathrm{a}},{ }^{\circ} \mathrm{C}\end{array} & \begin{array}{c}\text { Total } \\ \text { solar radiation } \\ \mathrm{W} \mathrm{m}^{-2}\end{array} \\ \text { January } & -11.1 & \\ \text { February } & -10.3 & 67 \\ \text { March } & -9.8 & 82 \\ \text { April } & -3.7 & 113 \\ \text { May } & 1.4 & 141 \\ \text { June } & 4.2 & 150 \\ \text { July } & 7.5 & 130 \\ \text { August } & 8.0 & 148 \\ \text { September } & 4.1 & 144 \\ \text { October } & -0.2 & 112 \\ \text { November } & -5.6 & 84 \\ \text { December } & -10.1 & 60 \\ & & 58\end{array}$

the warm season from May to September (October) and therefore the winter values in Table II are estimated by means of measurements taken at the state-network meteorological station, Terskol, $16 \mathrm{~km}$ from the glacier front, using a fixed temperature jump at the rock-glacier contact zone and measured vertical thermal gradients $(-0.5 \mathrm{deg} / 100 \mathrm{~m}$ of elevation for November-December, $-0.6 \mathrm{deg} / 100 \mathrm{~m}$ for January-February and July-October, $-0.7 \mathrm{deg} / 100 \mathrm{~m}$ for March-June). Calculation of $T_{\mathrm{a}}$ with the help of gradients usually agrees well with direct temperature measurements, the correlation coefficient always being greater than 0.9 .

\section{Total solar radiation, $Q_{\mathrm{S}}$}

Table II also lists the average monthly values of total solar radiation over the Djankuat glacier snout. Direct actinometric measurements on the snout have not been made during the last few years, and so the results of observations taken in the summer of 1972, distinguished by their high quality, were assumed as a basis. However, that season was also distinguished by exceptionally warm summer weather and consequently by extremely high ablation, and the most negative mass balance throughout the entire period of field observations. Therefore, in accordance with the heat-balance ratios, values of $Q_{S}$ were reduced to satisfy a long-term average annual ablation norm of $4.4 \mathrm{~m} /$ year for this part of the lower glacier course. The annual distribution of $Q_{\mathrm{S}}$ was deduced by means of linear regression between $Q_{\mathrm{S}}$ values on Djankuat glacier and on the high-mountain meteorological station, at Krestovy Pass (about $130 \mathrm{~km}$ from Djankuat glacier), since regular actinometric observations were not carried out at the nearest Terskol station, while the nearest insolation-measuring meteorological stations (Bermamyt, Schadzhatmaz, and Sukhumi) are at lower altitudes, thus not reflecting the solar regime of the glacial belt.

\section{Ice temperature, $T_{\mathrm{i}}$}

An ice temperature of $-0.3^{\circ} \mathrm{C}$ is used as the value at depth. This follows from thermometry done by L.A. Sukhanov in a $55 \mathrm{~m}$ deep bore hole in the glacier snout nearly to the bed (Boyarskiy, 1978). The lower level of zero seasonal temperature fluctuations lies approximately at a depth of $6-7 \mathrm{~m}$. Near the surface, the ice temperature can fall to $-15^{\circ}$ to $-20^{\circ} \mathrm{C}$ in winter while rising to $0^{\circ} \mathrm{C}$ in summer, but below $6-7 \mathrm{~m}$ it remains almost constant $\left(-0.2^{\circ}\right.$ to $-0.5^{3} \mathrm{C}$ ) down to the bed and its slight variations are of a random nature that cannot be separated from random measurement errors. Also, since the problem is dominated by the thermophysics of the phase transition, an error in $T_{\mathrm{i}}$ of $\pm 0.1{ }^{\circ} \mathrm{C}$ results in an error of no more than $0.1 \%$ in the calculations, negligible with respect to the other sources of errors.

The whole set of input parameters of the model used for computation for Djankuat glacier is given in Table III.

\section{DEBRIS THAWING-OUT}

To investigate changes in debris-cover thickness with time and the influence of moraine on ablation rate, a series of numerical calculations, using the formulation described in the section previous but one, were undertaken. Calculations deal only with that part of the ablation period after the disappearance of the seasonal snow cover on the snout, i.e. during the 3 months from 15 June to 15 September, thus dealing solely with melting of glacier ice.

For comparison, computations using a formulation based on an assumption of quasi-stationary temperature distributions within the moraine layer were also made. This assumption contradicts the non-steady nature of Stephan problems which arises as a result of the phase-boundary transition condition (6). The assumption may be admissable if the rate of establishment of the thermal regime in the moraine considerably exceeds the rate of moraine-thickness change, which is related to the movement of the phase boundary, i.e. if

$$
\frac{\lambda_{\mathrm{m}}}{C_{\mathrm{m}} \rho_{\mathrm{m}} h} \gg \frac{\mu}{1-p} \frac{\mathrm{d} \xi}{\mathrm{d} t} .
$$


TABLE III. NUMERICAL VALUES OF MODEL PARAMETERS

\begin{tabular}{|c|c|c|}
\hline Symbol & Parameter & Value \\
\hline$\rho_{\mathrm{i}}$ & Ice density & $880 \mathrm{~kg} \mathrm{~m}^{-3}$ \\
\hline$C_{\mathrm{i}}$ & Specific heat of ice & $1.88 \mathrm{~kJ} \mathrm{~kg}^{-1} \mathrm{deg}^{-1}$ \\
\hline$\lambda_{\mathrm{i}}$ & Thermal conductivity of ice & $2.51 \mathrm{~W} \mathrm{~m}^{-1} \mathrm{deg}^{-1}$ \\
\hline$T_{\mathrm{i}}$ & $\begin{array}{l}\text { Average temperature over depth, initial ice } \\
\text { temperature }\end{array}$ & $-0.3^{\circ} \mathrm{C}$ \\
\hline$\rho_{g}$ & Density of moraine rock (granite) & $2.6 \mathrm{Mg} \mathrm{m}^{-3}$ \\
\hline$C_{\mathrm{g}}$ & Specific heat of moraine rock (granite) & $1.26 \mathrm{~kJ} \mathrm{~kg}^{-1} \mathrm{deg}^{-1}$ \\
\hline$\lambda_{\mathrm{g}}$ & Heat conductivity of moraine rock (granite) & $2.8 \mathrm{~W} \mathrm{~m}^{-1} \mathrm{deg}^{-1}$ \\
\hline$p$ & Debris-cover porosity & 0.43 \\
\hline$\mu$ & Bulk debris concentration inside ice & $0.12 \%$ \\
\hline$\alpha$ & Initial surface albedo of debris-containing ice & 0.35 \\
\hline$\alpha_{g}$ & Moraine-cover albedo & 0.10 \\
\hline$Q_{\mathrm{S}}$ & Total solar radiation & $58-290 \mathrm{~W} \mathrm{~m}^{-2}$ \\
\hline$T_{\mathrm{a}}$ & Air temperature & $-10^{\circ}$ to $+10^{\circ} \mathrm{C}$ \\
\hline$Q$ & Latent heat of fusion of ice & $334 \mathrm{~kJ} \mathrm{~kg}^{-1}$ \\
\hline$T_{\mathrm{h}}$ & Ice melting-point & $0^{\circ} \mathrm{C}$ \\
\hline$y$ & Moraine-albedo decrement & $100 \mathrm{~m}^{-1}$ \\
\hline$b$ & Eddy heat-transfer coefficient & $11.6 \mathrm{~W} \mathrm{~m}^{-2} \mathrm{deg}^{-1}$ \\
\hline
\end{tabular}

For values of thermophysical parameters of debris cited in Table III and an ablation rate of approximately $4 \mathrm{~m}$ per melting season of mean length of about 3 months, the condition (23) is observed even for rather high values of $h$. It should be borne in mind, however, that the establishment of a stationary thermal regime in the moraine is quite impossible even at the end of the ablation season owing to temporal fluctuations in the insolation and the air temperature.

The ablation rate under the moraine layer $a_{\mathrm{m}}$ can be computed by

$$
a_{\mathrm{m}}=\frac{1}{\mu}(1-p)(1-\mu) \frac{\mathrm{d} h}{\mathrm{~d} t},
$$

if the function $h(t)$ is known. In the case of a quasistatinary regime, balance ratios give:

$$
a_{\mathrm{ms}}=\frac{\lambda_{\mathrm{m}}}{\rho_{\mathrm{i}}\left(Q-C T_{\mathrm{i}}\right)} \frac{Q_{\mathrm{S}}\left(1-\alpha_{\mathrm{m}}\right)+b T_{\mathrm{a}}}{b h+\lambda_{\mathrm{m}}} .
$$

This expression, with the initial temperature of debriscontaining ice $T_{\mathrm{i}}=0^{\circ} \mathrm{C}$, is identical to that cited by Khodakov (1973[a]). Equation (25) allows for properties of already formed moraine cover after the initial stage of its development. Use of Equation (25) in the limit when $h \rightarrow 0$ is incorrect if the moraine albedo does not tend to the ice albedo continuously. Use of Equation (21) permits analysis of the dependence of $a_{\mathrm{m}}$ on $h$.

The values of input parameters cited in Tables II and III were used for calculations with the proposed model which were done on a computer. Besides using the inferred debris concentration $\mu=0.12 \%$ evaluated for Djankuat glacier, other cases where $\mu$ was set to $0.5 \%, 1 \%$, and $5 \%$ were also run, bringing to light some of the thermophysical features of the debris thawing-out process.

An explicit numerical method with a non-uniform grid was used for calculations. The grid is deformable to take account of ice melting. This method is convenient for calculation of a Stephan-type problem with moving boundaries (Grigoryan and others, 1982).

Figure 4 illustrates the temporal dependence of moraine-cover thickness $h$ as a result of this process. For comparison, model results based on the quasi-stationary temperature formulation are also plotted using dashed lines. This formulation, using Equations (24) and (25), requires step integration

$$
\begin{aligned}
& \quad h_{\mathrm{s}}\left(t_{\mathrm{k}}\right)=h_{\mathrm{s}}\left(t_{\mathrm{k}-1}\right)+ \\
& +\frac{\lambda_{\mathrm{m}} \mu}{\rho_{\mathrm{i}}\left(Q-c T_{\mathrm{i}}\right)(1-\mu)} \frac{Q_{\mathrm{s}}\left(t_{\mathrm{k}-}\right)\left(1-\alpha_{\mathrm{m}}\right)+b T_{\mathrm{a}}\left(t_{\mathrm{k}-1}\right)}{(1-p)\left[b h_{\mathrm{s}}\left(t_{\mathrm{k}-1}\right)+\lambda_{\mathrm{m}}\right]} \Delta t
\end{aligned}
$$

where $\Delta t$ is the time step. Figure 4 shows that the quasistationary formulation underestimates $h$, the deviation increasing in time. However, the relative deviation between stationary and non-stationary solutions declines with $\mu$ and elapsed time. As calculations show, every curve has an inflection point near the start; this point corresponds to the critical value

$$
h_{\mathrm{cr}}=2-3 \mathrm{~cm}
$$




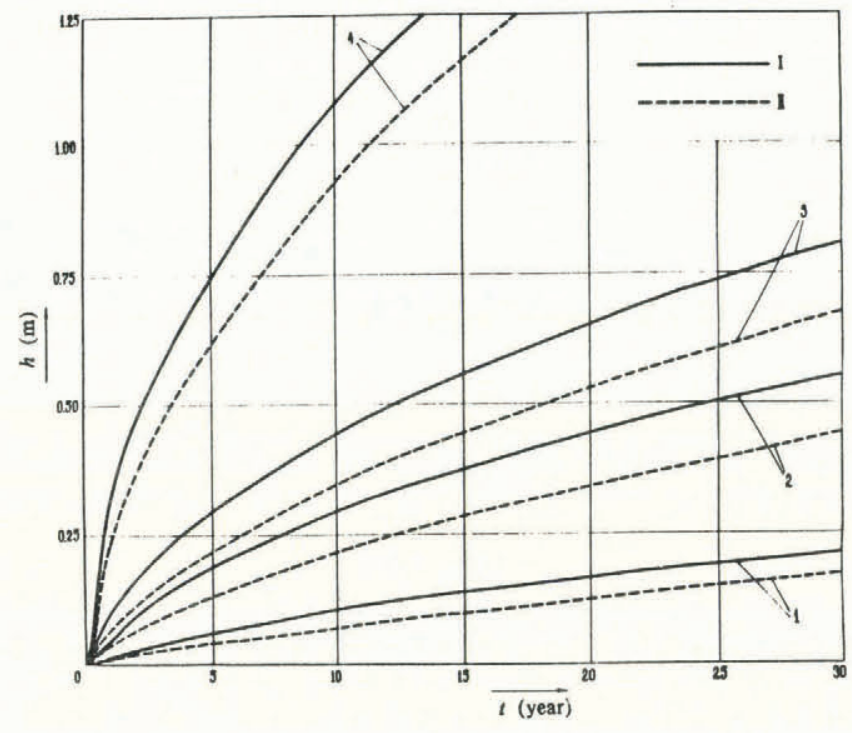

Fig. 4. Moraine-cover thickness dependence on time. I, non-steady solution; II, quasi-stationary solution. $1,2,3$, and 4 correspond to $\mu=0.12 \%, 0.5 \%, 1 \%$, and $5 \%$.

that coincides with the maximum rate of increase of the debris-layer thickness and hence of the sub-moraine ablation rate $a_{\mathrm{m}}$. The value $h_{\mathrm{cr}}$ conforms to observed effects of ablation intensification beneath the moraine layer (Østrem, 1959; Kreiter and Tikhanovskaya, 1964; Kreiter, 1965; Kamalov, 1967; Dolgushin and others, 1972; Khodakov, 1972[a]; Demchenko and Sokolov, 1982). The time elapsed until $h_{\mathrm{cr}}$ is reached diminishes with the concentration. For a debris concentration of $\mu=0.12 \%$ (Djankuat glacier case), $h_{\mathrm{cr}}$ is attained by the third year; in 30 years the thickness of the moraine layer caused by debris thawing out should reach $\sim 30 \mathrm{~cm}$, which is accompanied by deceleration of moraine-cover growth. Its growth sharply increases with increase of $\mu$; thus, when $\mu=1 \%$, the half-metre thick moraine layer is reached after 12 years, but when $\mu=5 \%$ it takes only 2.5 years. The computation suggests that the stabilization of debris-cover thickness occurs when

$$
h \approx 2-3 \mathrm{~m} \text {. }
$$

The dynamics of debris-cover growth are connected intimately with the sub-moraine ablation rate. The temporal relationships of $a_{\mathrm{m}}$ are shown in Figure 5. Use of Equation (21) relating surface albedo to moraine-layer thickness is shown to lead to the appearance of maxima corresponding to a moraine thickness of $2-3 \mathrm{~cm}$. When $\mu$ rises, these maxima move to the left, i.e. the time required to reach them decreases. Diminution of the sub-moraine ablation rate with the growth of $h$ is due to the shielding

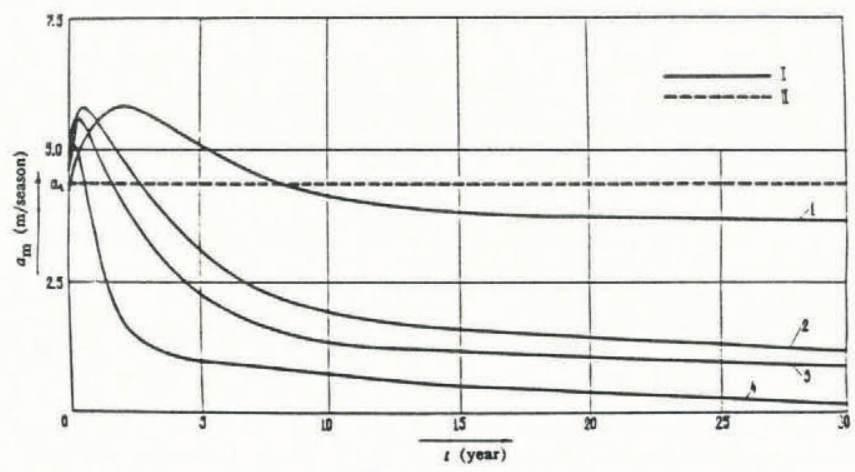

Fig. 5. Sub-moraine ablation-rate dependence on time. I, curves $a_{m}(t) ; I I$, ablation rate $a_{i}$ on a clean-ice surface. $1,2,3$, and 4 correspond to $\mu=0.12 \%, 0.5 \%, 1 \%$, and $5 \%$. effect of the debris cover which is also affected by its relatively low heat conductivity. The dashed line marks the ablation rate for clean ice in the melting season. This quantity can be estimated from the balance equations, so:

$$
a_{\mathrm{i}}=\frac{1}{\rho_{\mathrm{i}}\left(Q-c T_{\mathrm{i}}\right)} \int_{t_{0}}^{t_{1}}\left[Q_{\mathrm{S}}(t)\left(1-\alpha_{\mathrm{m}}\right)+b T_{\mathrm{a}}(t)\right] \mathrm{d} t,
$$

where $t_{0}$ and $t_{1}$ are the beginning and the end of the ice ablation season. Results using Equation (27) for conditions appropriate to Djankuat glacier give an average seasonal ice-ablation rate

$$
a_{\mathrm{i}}=4.36 \mathrm{~m} \mathrm{year}^{-1} \text {. }
$$

Thermal shielding of the debris cover begins when the submoraine ablation rate decreases back to $a_{\mathrm{j}}$. The equivalent time elapsed until the beginning of the shielding effect, $t_{\mathrm{e}}$, diminishes abruptly with increases in the debris concentration. Thus, when $\mu=0.12 \%$ (Djankuat glacier case) corresponds to $t_{\mathrm{e}}=8$ years but for $\mu=5 \%, t_{\mathrm{e}}=0.6$ years only. The dependence of the equivalent time on $\mu$ is shown in Figure 6. These results are extremely interesting because by estimating the debris concentration in the ice it is

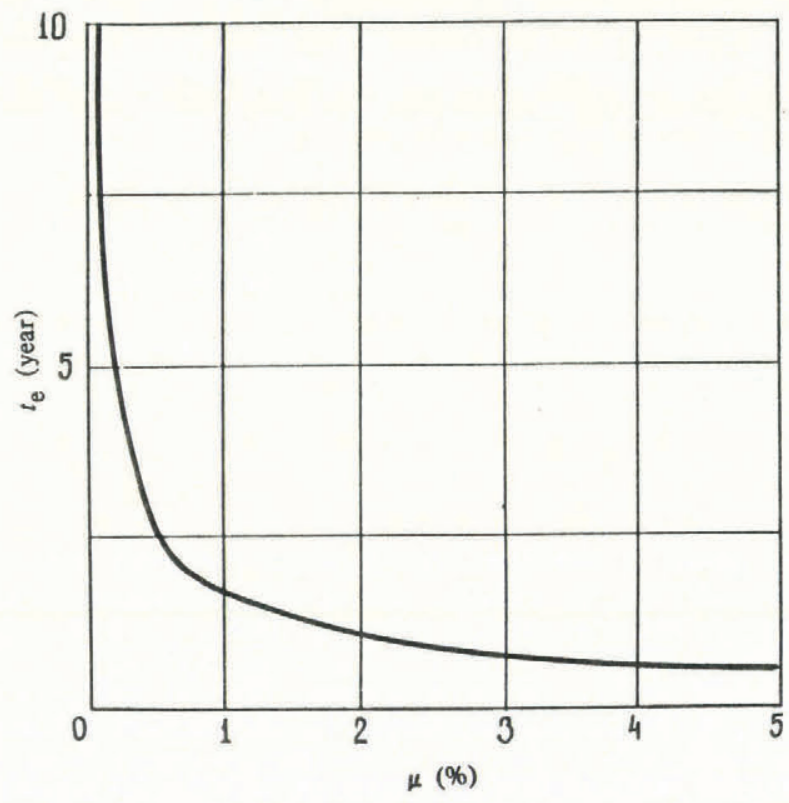

Fig. 6. Equivalent time $t_{e}$ dependence on debris concentration.

possible to estimate the time span during which an augmentation of liquid run-off from a glacier should be expected. Furthermore, when $t>t_{\mathrm{e}}$, the shielding stage commences. In this way, a glacier covered with a welldeveloped moraine envelope serves as a self-controlling system with respect to run-off under natural conditions.

During the shielding stage the development of the moraine cover leads to a rapid diminution of sub-moraine ablation. This effect can be observed not only in Figure 5 but also in Figure 7 where the temporal dependence of the relative sub-moraine ablation rate is illustrated. For glaciers with a comparatively small debris content, it takes rather a long time to achieve the self-armouring effect and there is a relatively slight decrease in the surface ice-melting rate later on. When the debris content is high $(\mu>1 \%)$, thermal development evolves rapidly; the self-armouring effect is reached in the first few years and is followed by the formation of a thick debris cover, and in 20-30 years by the practical cessation of sub-moraine ablation due to atmospheric heat penetration.

Because of the faint thermal inertia, the maximum of 


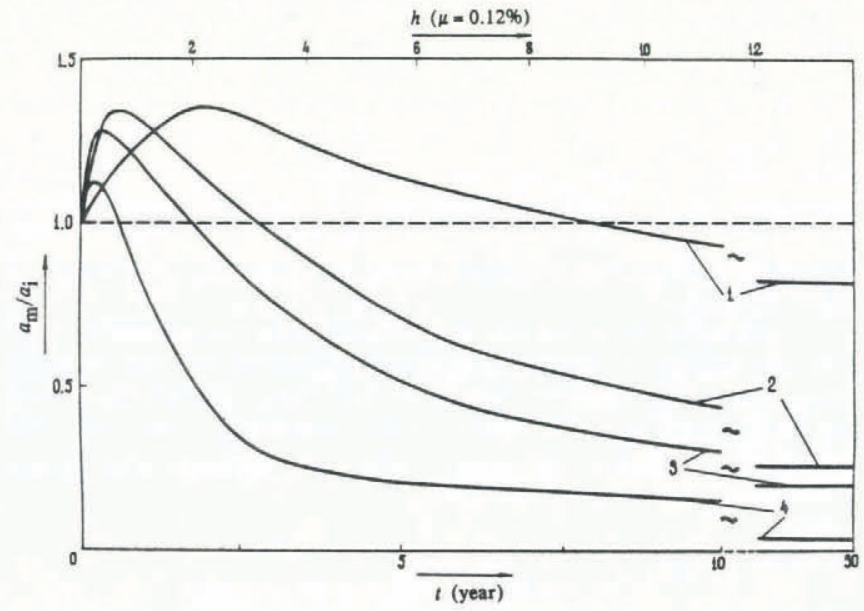

Fig. 7. Non-dimensional ablation rate $a_{m} / a_{i}$ dependences on time (lower scale) and on moraine-cover thickness for the Djankuat glacier case with $\mu=0.12 \%$ (upper scale). 1,2 , 3 , and 4 correspond to $\mu=0.12 \%, 0.5 \%, 1 \%$, and $5 \%$.

$a_{\mathrm{m}} / a_{\mathrm{i}}$ is higher for small values of $\mu$ than for high concentrations; thus, when $\mu=0.12 \%$ the maximum sub-moraine ablation rate is 1.35 times higher than the ablation rate for clean ice. This ratio decreases considerably with increases in $\mu$. In other words, debris concentration appears in the role of a regulator of not only the duration of augmentation of the glacial run-off period but also of the amplitude of this augmentation.

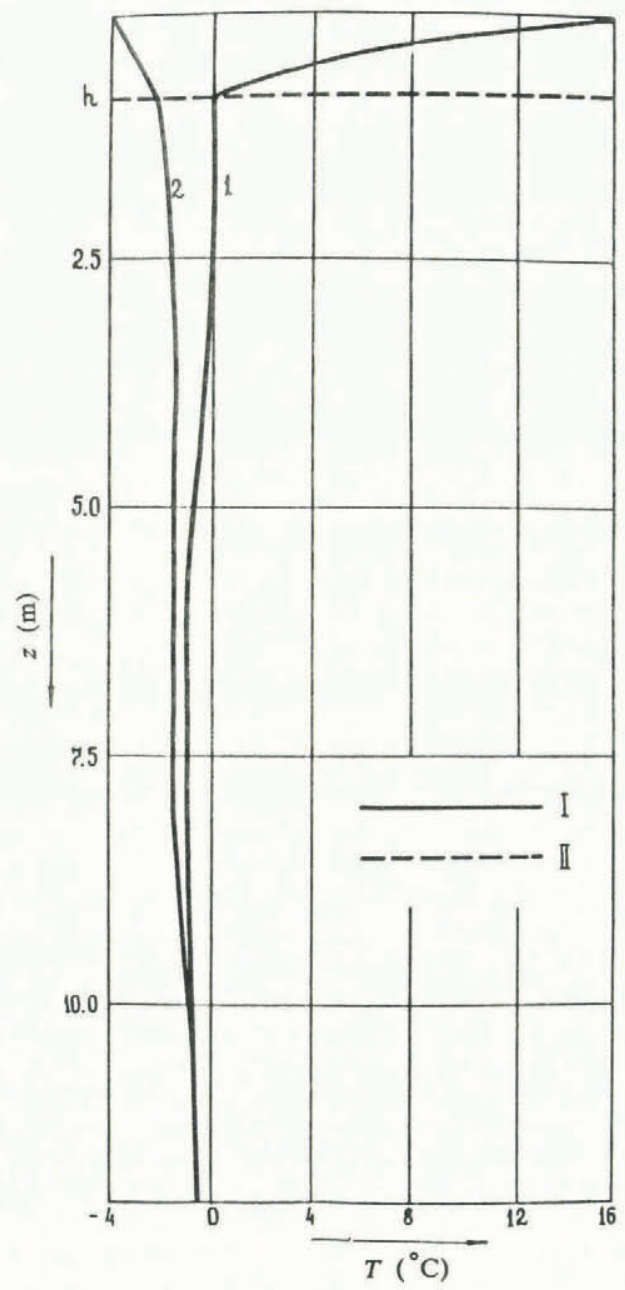

Fig. 8. Moraine- and ice-temperature dependence on depth, for $\mu=1 \%$. I, temperature curves with depth; II, lower limit of debris layer. 1, temperature by 15 August; 2, temperature by 1 March.
Figure 8 shows curves for temperature against depth for different seasons, e.g. in the thirtieth year after the commencement of debris thawing out when the concentration $\mu=1 \%$. It is clear that the temperature does not become fixed in the upper $80 \mathrm{~cm}$ corresponding to the moraine layer. In the ablation season, by 15 August (curve 1) the moraine surface is heated up to $16^{\circ} \mathrm{C}$, more than twice the average monthly air temperature (see Table II). A seasonal heat wave moving through the moraine cover pushes the winter cold wave downward and creates a temperature maximum in the ice. A similar phenomenon has been observed for the migration of the lower limit of the seasonal thawing layer within the permafrost zone (Grigoryan and others, 1982). In winter, the moraine temperature is below zero (curve 2). Both temperature curves join up in the ice at a depth of about $8 \mathrm{~m}$, where seasonal fluctuations fade away. For Djankuat glacier, in the thirtieth year of debris thawing out the summer temperature of the surface $\sim 30 \mathrm{~cm}$ moraine cover is about $+10^{\circ} \mathrm{C}$; due to the relatively small moraine-cover thickness, the major part of the heat supply in summer is expended on sub-moraine ablation, as is evident from Figures 4,5 , and 7.

All the calculations using a value of $\mu=0.12 \%$ match well with observations from Djankuat glacier. Thus, the mean thickness of moraine cover formed during 1968-83 on the representative area was found to be $13 \mathrm{~cm}$ according to the direct moraine survey, while from Figure 4 after 14 years the accumulated debris layer is computed to be $13.3 \mathrm{~cm}$ thick. Furthermore, direct stake measurements of sub-moraine ablation over the representative area where debris thickness was about $12 \mathrm{~cm}$ showed a $10 \%$ decrease in ablation relative to the adjacent areas of clean ice; $a_{\mathrm{m}} / a_{\mathrm{i}}$ is found to be equal to 1 in areas where the debris cover is about $8 \mathrm{~cm}$ thick. Both of these results agree with Figure 7 (curve 1) quite well with only a slight tendency towards overestimation of values of $a_{\mathrm{m}} / a_{\mathrm{i}}$. Figure 8 illustrates the considerable attenuation of seasonal temperature fluctuations to practically zero below 7-8 m. Stabilization of negative $T_{i}$ values in the lower horizons to within a few tenths of a degree as was indicated by bore-hole thermometry. Hence, the proposed model may also be used in a predictive mode, in the first instance for mass-balance calculations on glaciers.

\section{THE SHIELDING ROLE OF THE DEBRIS COVER}

When its thickness increases, the moraine cover on the ice surface begins playing the role of a heat screen (when $\left.t>t_{\mathrm{e}}\right)$. The growth of the debris-layer thickness leads to the expansion of the frequency spectrum of oscillations caused by external heat influences that attenuate within it. An harmonic air-temperature wave with a frequency $\omega$

$$
T_{\mathrm{a}}=A_{0} \cos \omega t
$$

is known to cause thermal perturbations in an homogeneous medium with a free surface (Tikhonov and Samarskiy, 1972):

$$
T=A_{\mathrm{o}} \exp \left[-\sqrt{\frac{\omega}{2 k}} z\right) \cos \left(\omega t-\sqrt{\frac{\omega}{2 k}} z\right)
$$

where $k=\lambda / c \rho$ is the thermal diffusivity of the medium. As can be seen from Equation (29), the attenuation decrease defines the depth $h *$ of the medium layer at which the amplitude of an initial wave diminishes by a factor of $e$ :

$$
h_{*}=\sqrt{\frac{2 k}{\omega}}
$$

Using the thermophysical parameter values listed in Table III for granitic moraine in Equation (30), daily temperature oscillations $\left(\omega=2 \pi / 24 \mathrm{~h}^{-1}\right)$ fade out strongly in a debris layer of thickness

$$
h_{\mathrm{d}} \approx 0.16 \mathrm{~m} \text {. }
$$


Seasonal oscillations of external genesis $\left(\omega=2 \pi / 2160 \mathrm{~h}^{-1}\right)$ fade out in a layer of thickness

$$
h_{\mathrm{S}} \approx 1.54 \mathrm{~m} \text {. }
$$

Annual temperature oscillations $\left(\omega=2 \pi / 8720 \mathrm{~h}^{-1}\right)$ fade out in a moraine layer of thickness

$$
h_{\mathrm{y}} \approx 3.1 \mathrm{~m} \text {. }
$$

Estimates from Equations (31)-(33) depend considerably on the moraine thermal conductivity determined with the help of formulae (4); in the Djankuat glacier case it is equal to $1.6 \mathrm{~W} \mathrm{~m}^{-1} \mathrm{deg}^{-1}$. If moraine consists of macroclastic material, $\lambda_{m}$ may be much higher and then the corresponding values for Equations (31)-(33) should be increased by $20-25 \%$. A debris layer of several metres thickness thus isolates the underlying ice from the thermal influence of the atmosphere almost completely. Nevertheless, even in such cases, sub-moraine ice melting during the summer season may occur because of the filtration of melt and rain water through the debris cover. According to various hydrological estimates, the rate of water filtration through different materials, including coarse-grained materials with high permeability, does not exceed $0.005-0.01 \mathrm{~m} / \mathrm{s}$ under low heads. Then, according to Equations (14) and (15), and using a kinematic viscosity for water of $v=1.3 \times 10^{-6} \mathrm{~m}^{2} / \mathrm{s}$ (Vagaftik, 1963), sub-moraine ablation caused by heat transfer by filtering melt water with temperature $\sim 0.2^{\circ} \mathrm{C}$ comes approximately to $0.05 \mathrm{~m}$ per summer season of about 3 months. This value does not exceed $2 \%$ of the seasonal ablation rate from a clean ice surface as in Equation (28). After a time the thick debris cover consolidates and densifies which is accompanied by granulometric fractionation (Small, 1983). Thus, the moraine roof insulates the ice not only from heat but also from rainfall. Indeed, the existence of buried and stagnant glaciers through dozens and hundreds of years would not be possible without this effect.

So, the thawing out of ice from a moraine serves to "self-armour" (Khodakov, 1972[a]) a glacier during its thermal evolution. Debris cover, acting as a heat screen, cuts off separate glacier surface sections from participation in the thermal evolution and also promotes its insolation from mechanical activity.

The glacial degradation leads to geomorphological levelling of parts of the glacier surface shielded by moraine. At first, they differ from other glacier areas as they look like raised areas armoured by the debris cover and afterwards like insulated ice having no connection with the dynamics of the main glacier. Such features may be classified as dead ice (Shumskiy, 1955; Vtyurin, 1981).

Glacier advances lead to the burial of stagnant glacier parts and to the formation of dead-ice cores inside the glacier body. Such cores, in Shumskiy's opinion, may even play the role of a bed over which a glacier moves. Furthermore, under certain conditions, dead-ice cores may turn into a stage of "buried glacial ice" (Vtyurin, 1981) with changes in texture and structure (Shumskiy, 1955) That stage can last a rather long time, of the order of thousands of years.

As was mentioned above, morainic "armour" is able to preserve buried ice from rainfall of usual intensity; anomalous showers considerably exceeding the precipitation norm may still move the debris cover away. Thus, on 18-19 July 1983, extremely intense showers in the Caucasus caused many mudflows that caused slumping and mudflow removal of the thick debris cover from stagnant parts of the marginal moraine ramparts of Djankuat glacier dating back to the maximum of the Fernau stage (seventeenth century), and from the steep part of the terminus. As a result, these processes exposed buried ice of azure hue which resumed thawing at its surface.

\section{BLACKENING OF A GLACIER SURFACE}

One of the most important aspects of glacial activity in the alpine zone is liquid run-off. This is governed in the summer mainly by ablation from glacier surfaces. Due to the irregular distribution of morainic matter within the ice and on its surface, the ice-thawing rate can vary greatly over a glacier. Here, technical and scientific problems arise concerning the influence of glacier-surface blackening on the augmentation of its run-off and the economic impact of this effect. These problems are closely connected with the question of an artificial influence on natural objects which is itself within the bounds of general problems of the rational utilization of natural resources and the protection of the environment.

In order to estimate the sub-moraine ice-thawing rate, let us use the quasi-stationary approximation for the thermal regime in the moraine layer; in this case, the ablation rate is expressed by Equation (25). Assuming that all the absorbed radiation is used only for melting, the clean ice-thawing rate $a_{\mathrm{i}}$ is defined by

$$
a_{\mathrm{i}}=\frac{1}{\rho_{\mathrm{i}}\left(Q-c T_{\mathrm{i}}\right)}\left[Q_{\mathrm{s}}(1-\alpha)+b T_{\mathrm{a}}\right]
$$

For the values cited in Table $\mathrm{I}, a_{\mathrm{m}} / a_{\mathrm{i}}=1.3-1.5$, i.e. the maximum sub-moraine ablation rate can be one and a half of that for clean-ice surfaces (Fig. 7). On high-latitude and high-mountain glaciers, where the total solar radiation $Q_{S}$ is relatively high and the air temperature $T_{\mathrm{a}}$ in summer is low, the ratio $a_{\mathrm{m}} / a_{\mathrm{i}}$ can be still higher, reaching 2-3 for snow-covered surfaces with a very high albedo.

Aspects of the artificial blackening of a glacier surface can now be discussed. In this case, the cover thickness generally is so small that the thermal state within the layer can be ignored; instead we let the free surface have the same albedo $\alpha_{c}$ as the covering material. Then the ablation rate $a_{\mathrm{c}}$ is calculated according to a formula similar to Equation (34) and the ratio $a_{\mathrm{c}} / a_{\mathrm{i}}$ is determined by the expression:

$$
\frac{a_{c}}{a_{\mathrm{i}}}=\frac{Q_{\mathrm{S}}\left(1-\alpha_{\mathrm{c}}\right)+b T_{\mathrm{a}}}{Q_{\mathrm{s}}(1-\alpha)+b T_{\mathrm{a}}} .
$$

Suppose that a black substance with a very low albedo $\alpha_{c} \ll 1$ is distributed over the clean-ice surface. In this case Equation (35) becomes:

$$
\frac{a_{\mathrm{c}}}{a_{\mathrm{i}}} \approx 1+\frac{\alpha Q_{\mathrm{S}}}{(1-\alpha) Q_{\mathrm{s}}+b T_{\mathrm{a}}} .
$$

Ablation will thus be augmented by artificial blackening when the following natural conditions are observed:

1. The surface-ice albedo under natural conditions should be comparatively high. Glaciers in high-latitude and high-mountain zones with solid precipitation during the summer seasons satisfy this condition.

2. Air temperature should be rather low; this is found in alpine belts.

3. Shearing in the wind flow promoting convective heat exchange between the ice surface and the air should be relatively small. This factor depends mainly on local meteorological conditions, the topography, and the orography of the non-glacierized area.

Proceeding from these conditions, it is possible to subdivide existing alpine glacierization into separate areas with respect to their potential run-off augmentation arising from artificial surface blackening. If multi-year average distributions of the parameters of formula (36) in the ablation season (say, decade means) are known, the prediction of expected glacial run-off augmentation can be made by using

$$
\frac{R_{\mathrm{c}}}{R_{\mathrm{i}}}=\sum_{\mathrm{k}=1}^{N}\left(\bar{Q}_{\mathrm{S}}+\bar{b} \bar{T}_{\mathrm{a}}\right)_{\mathrm{k}} \Delta t_{\mathrm{k}} / \sum_{\mathrm{k}=1}^{N}\left[\bar{Q}_{\mathrm{s}}(1-\bar{\alpha})+\bar{b} \bar{T}_{\mathrm{a}}\right]_{\mathrm{k}} \Delta t_{\mathrm{k}}
$$


where $R_{\mathrm{c}}$ and $R_{\mathrm{i}}$ are the liquid run-off volumes from the unit area during the ablation period for blackened ice and clean ice, respectively; $N$ is the number of time steps $\Delta t_{k}$ comprising the ablation period; the bar denotes values averaged over the corresponding time span $\Delta t_{\mathrm{k}}$. Equation (37) may be used as a basis for dividing glacierization into areas of differing potential for liquid run-off augmentation caused by blackening.

In previous papers (Avsyuk, 1953; Kreiter and Tikhanovskaya, 1964; Kreiter, 1965; Kamalov, 1967; Tikhanovskaya, 1970[a]), blackening has been discussed in terms of surface soiling or distribution of thin layers of dust or powdery matter with a low albedo over a glacier surface. Such experiments have been carried out (Kreiter and Tikhanovskaya, 1964; Kreiter, 1965) but this method is of limited effectiveness for the following reasons. First, the soiling process is difficult to execute when the substance has to be dispersed from a helicopter. Secondly, because of the peculiarity of highland conditions, it is almost impossible to ensure effective distribution of the blackening substance over large areas since the major part of the substance is carried by wind beyond the glacier limits and on the glacier itself the black cover has an extremely irregular thickness. Thirdly, in melt seasons, the blackening substance is removed by surface streamlets very soon after its deposition, meaning that its influence is only transitory. Fourthly, the distribution of the blackening layer with a thickness of even $1 \mathrm{~cm}$ over sufficiently large areas demands an enormous mass of the blackening substance and consequently titanic volume of aircraft work. For example, blackening over $1 \mathrm{~km}^{2}$ of a glacier surface by a substance with a density $\rho_{b}=1000 \mathrm{~kg} / \mathrm{m}^{3}$ would require $10^{4}$ tonnes of such a substance!

However, there is another method of blackening the glacier surface - that of spreading a thin plastic film. Such a film must be purpose-made and possess the following qualities. It must be durable, thin, black, and it must adhere well to an icy surface. The first two requirements are quite feasible since the technology for manufacturing thin and durable film exists. The third one may be fulfilled by using soot as a filler in the manufacturing process. The fourth requirement is indispensable so as to prevent the film from warping and parting from the ice under wind action. This requirement may be easily satisfied by producing a film of wettable material, in which it will adhere to the ice by surface-tension forces arising as a result of the presence of melt water acting on the bottom surface of the film.

The thinness of the film permits a considerable reduction in the expenditure on material required for blackening glacier surfaces. The covering for an area of $1 \mathrm{~km}^{2}$ by a film $50 \mu \mathrm{m}$ thick and with polymer density $\rho_{\mathrm{p}}=1200 \mathrm{~kg} / \mathrm{m}^{3}$ would weigh only 60 tonnes. This can be manufactured in the form of separate rolls; a single roll of such a film $2 \mathrm{~m}$ wide and $300 \mathrm{~m}$ long should weigh about $20 \mathrm{~kg}$. Helicopters could easily deliver such rolls to places where they are needed on the chosen glacier, and then specially trained teams of mountaineers and glaciologists would be able to spread the film cover over the surface. Here the problem of fastening film edges at some points so as to avoid slip arises, but it is technically surmountable without any particular trouble.

The film thinness also allows the short-wave part of the solar spectrum to penetrate through it and hence to increase the effect of insolation on ice thawing.

An absolute run-off value calculation of superficial ablation beneath the film over an area $S$ can be made, according to Equation (37) with the expression

$$
V_{\mathrm{c}}=R_{\mathrm{c}} S=\sum_{\mathrm{k}=1}^{N}\left(\bar{Q}_{\mathrm{s}}+\bar{b} \bar{T}_{\mathrm{a}}\right)_{\mathrm{k}} \Delta t_{\mathrm{k}} S .
$$

For instance, film blackening of an area $1 \mathrm{~km}^{2}$ with initial surface albedo $\alpha \approx 0.4-0.5$, when average insolation is approximately $230 \mathrm{~W} \mathrm{~m}^{-2}, b=12 \mathrm{~W} \mathrm{~m}^{-2} \mathrm{deg}^{-1}$ and $T_{\mathrm{a}}=5^{\circ} \mathrm{C}$, leads to doubling of the ablation (in comparison with clean-ice ablation) during a melting season of $100 \mathrm{~d}$ long and produces an extra $5 \times 10^{6} \mathrm{~m}^{3}$ of water. A common irrigation requirement for agriculture is $\sim 1 \mathrm{~m} / \mathrm{m}^{2}$ per season (Kharchenko, 1981); this quantity of water should be sufficient for watering an additional area of $500 \mathrm{ha}$.

The suitability of a glacier for artificial blackening of its surface is constrained by the requirements of environmental protection. Briefly, these requirements can be formulated as: preservation of the affected object; maintenance of mudflow security conditions; preservation of channels of mountain streams.

These conditions show the preliminary work that needs to be done before the development of plans for the artificial augmentation of ablation. In particular, it is desirable to affect simultaneously relatively small areas of a number of glaciers so that fluctuations in the run-off from each glacier do not differ greatly from the natural discharge of their rivers. The total effect of obtaining the additional volume of melt water in these cases should not cause a strongly marked divergence from natural equilibrium conditions. In order to retrieve ice resources on affected glaciers, objects that can be influenced by engineering work may be changed or alternated from season to season.

\section{CONCLUSIONS}

A non-steady mathematical model of debris thawing out on to the surfaces of mountain glaciers has been formulated which can be used not only for the estimation of possible run-off augmentation from glaciers in different regions, but also for predicting moraine-cover evolution and sub-moraine ablation due to climatic changes over 30-50 years. Further development of the model requires the representation of additional processes affecting the moraine-cover thickness. These are due first to mass influx from valley walls, marginal moraines, and mass outflow due to debris sliding along the ice surface, and secondly to the re-distribution of morainic mass with glacier movement (Khodakov, 1974). Here, a coupled problem relating debris thawing out and glacier surface-layer kinematics has to be solved because the velocities of ice ablation under the moraine and debris-particle displacement along the surface are comparable.

It ought to be emphasized that all the processes mentioned are essentially non-steady. Also, for a glacier as a whole, it is advisable to consider three-dimensional formulations in order to ascertain the influence of nonuniformity not only on debris concentration but also on glacier-surface velocities; non-uniformity of moraine content with depth is also of importance.

Finally, the effect on sub-moraine ablation and, consequently, glacier run-off "self-control" or "self-armouring" by debris-cover development (Khodakov, $1972[\mathrm{~b}], 1974)$ is delicate enough to show how complicated glaciological objects are and at the same time how susceptible they are to any kind of exterior, and in particular anthropogenic, influence.

\section{REFERENCES}

Avsyuk, G.A. 1953. Iskusstvennoye usileniye tayaniya l'da i snega gornykh lednikov. [Artificial enhancing of ice and snow melting of mountain glaciers]. Trudy Instituta Geografii Akademii Nauk SSSR, Tom 56.

Birch, F., and others. 1942. Handbook of physical constants, by F. Birch, J. Schairer, and H.C. Spicer. New York, Geological Society of America.

Boyarskiy, I. Ya., ed. 1978. Lednik Djankuat. [The Djankuat glacier]. Leningrad, Gidrometeorologicheskoye Izdatel'stvo.

Demchenko, V.V., and Sokolov, L.N. 1982. Povyshennaya ablyatsiya l'da pod sloyem moreny $v$ usloviyakh Vostochnogo Pamira. [Increased ice ablation under a moraine layer in the conditions of the eastern Pamirs]. Materialy Glyatsiologicheskikh Issledovaniy. Khronika. Obsuzhdeniya, Vyp. 45, p. 119-21.

Denisov, Yu.M. 1980. Metod rascheta vliyaniya morennykh otlozheniy na tayaniye lednikov. [Method of calculation of debris influence on glacier thawing]. Trudy Sredneaziatskogo Nauchno-Issledovatel'skogo Instituta, Vyp. 71(152), p. 67-80. 
Dolgushin, L.D., and others. 1972. Vliyaniye eolovoy zapylennosti lednikov i poverkhnostnoy moreny na tayaniye lednikov Sredney Azii. [The influence of aeolian dusting of glaciers and superficial moraine on glacier thawing in Central Asia]. By L.D. Dolgushin, I.M. Lebedeva, G.B. Osipova, and O.V. Rototayeva. Materialy Glyatsiologicheskikh Issledovaniy. Khronika. Obsuzhdeniya, Vyp. 20, p. 108-16.

Grigoryan, S.S., and others. 1982. Kolichestvennyy prognoz temperaturnovo rezhima protaivayuschikh i promerzayuschikh gruntov. [The quantitative prognosis of the thermal regime of thawing and freezing grounds]. By S.S. Grigoryan, M.S. Krass, V.V. Lovchuk, and V.O. Mikhaylov. (In Matematicheskiye modeli $v$ geokriologii. Moscow, Izdatel'stvo MGU, p. 3-19.)

Higuchi, K., and Nagoshi, A. 1977. Effect of particulate matter in surface snow layers on the albedo of perennial snow patches. [Union Géodésique et Géophysique Internationale. Association Internationale des Sciences Hydrologiques. Commission des Neiges et Glaces.] Symposium. Isotopes et impuretés dans les neiges et glaces. Actes du colloque de Grenoble, août/septembre 1975 , p. 95-97. (IAHS-AISH Publication No. 118.)

Izdatel'stvo Nedra. 1976. Spravochnik geofizika. Tom 1. [Handbook of a geophysician. Vol. I]. Moscow, Izdatel'stvo Nedra.

Kamalov, B.A. 1967. O vliyanii tayaniya l'da pod morennym pokrovom. [On the ice thawing under the moraine cover]. Trudy Sredneaziatskogo regional'nago NauchnoIssledovatel'skogo Gidrometeorologicheskogo Instituta, Vyp. $30(45)$, p. 19-25.

Kharchenko, S.I. 1981. Vliyaniye orositel'nykh melioratsiy na stok. [Irrigating melioration influence on the run-off]. (In Shestakov, V.M., ed. Nekotoryye voprosy sovremennoy nauchnoy $i$ prakticheskoy gidrologii. Chast' 1. [Some problems of present-day scientific and practical hydrology. Part 1]. Moscow, Izdatel'stvo MGU, p. 60-71.)

Khodakov, V.G. 1972[a]. Raschet ablyatsii l'da pod sloyem moreny. [Calculation of ice ablation under moraine layer]. Materialy Glyatsiologicheskikh Issledovaniy. Khronika. Obsuzhdeniya, Vyp. 20, p. 105-08.

Khodakov, V.G. 1972[b]. Raschet i prognoz ablyatsii morenosoderzhashchego l'da. [Calculation and prognosis of debris-containing ice ablation]. Materialy Glyatsiologicheskikh Issledovaniy. Khronika. Obsuzhdeniya, Vyp. 20 , p. 215-18.

Khodakov, V.G. 1974. Osobennosti formirovaniya balansa l'da pul'siruyuschego lednika Kolka. [Peculiarities of mass balance formation of the surging Kolka glacier]. Materialy Glyatsiologicheskikh Issledovaniy. Khronika. Obsuzhdeniya, Vyp. 24, p. 116-25.

Konovalov, V.G. 1979. Raschet $i$ prognoz tayaniya lednikov Sredney Azii. [Calculation and prognosis of melting of glaciers of Central Asia]. Leningrad, Gidrometeoizdat.
Kotlyakov, V.M. 1968. Snezhnyy pokrov Zemli i ledniki. [The Earth's snow cover and glaciers]. Leningrad, Gidrometeorologicheskoye Izdatel'stvo.

Kreiter, A.A. 1965. Primeneniye sortirovochnoy pyli pri iskusstvennom zapylenii snega. [Utilization of sorted dust for artifical snow soiling]. Materialy Glyatsiologicheskikh Issledovaniy. Khronika. Obsuzhdeniya, Vyp. 11, p. 270-71.

Kreiter, A.A., and Tikhanovskaya, A.A. 1964. Izmeneniye teplo- i vlagoobmena lednikovoy poverkhnosti pod deystviyem iskusstvennovo zapyleniya. [Alteration of heat and liquid exchange on a glacier surface under the influence of artifical soiling]. Materialy Glyatsiologicheskikh Issledovaniy. Khronika. Obsuzhdeniya, Vyp. 10, p. 277-79.

Lebedeva, I.M. 1972. Ispareniye s lednikov Sredney Azii [Evaporation from the glaciers of Central Asia]. Materialy Glyatsiologicheskikh Issledovaniy. Khronika. Obsuzhdeniya, Vyp. 20, p. 94-105.

Mikheyev, M.A., and Mikheyeva, I.M. 1977. Osnovy teploperedachi. [Bases of heat transfer]. Moscow, Izdatel'stvo Energiya.

Østrem, G. 1959. Ice melting under a thin layer of moraine, and the existence of ice cores in moraine ridges. Geografiska Annaler, Vol. 41, No. 4, p. 228-30.

Shumskiy, P.A. 1955. Osnovy strukturnogo ledovedeniya. [Principles of textural ice research]. Moscow, Izdatel'stvo Akademii Nauk SSSR.

Small, R.J. 1983. Lateral moraines of Glacier de Tsidjiore Nouvo: form, development, and implications. Journal of Glaciology, Vol. 29, No. 102, p. 250-59.

Tikhanovskaya, A.A. 1970[a]. K voprosu o tayanii l'da pod morennym pokrovom. [On the question of sub-moraine ice thawing]. Trudy Sredneaziatskogo NauchnoIssledovatel'skogo Gidrometeorologicheskogo Instituta, Vyp. 56(71), p. 97-106.

Tikhanovskaya, A.A. 1970[b]. Nekotoryye voprosy izmeneniy radiatsionnovo balansa na zamorenennoy poverkhnosti l'da. [Some aspects of radiation balance changes over the moraine-covered part of a glacier]. Trudy Sredneaziatskogo Nauchno-Issledovatel'skogo Gidrometeorologicheskogo Instituta, Vyp. 56(71), p. 92-96.

Tikhonov, A.N., and Samarskiy, A.A. 1972. Uravneniya matematicheskoy fiziki. [Equations of mathematical physics]. Moscow, Izdatel'stvo Nauka.

Tronov, M.V. 1966. Ledniki $i$ klimat. [Glaciers and climate]. Leningrad, Gidrometeorologicheskoye Izdatel'stvo.

Vagaftik, N.B. 1963. Spravochnik po teplofizicheskim svoystvam gazov $i$ zhidkostey. [Handbook of thermophysical properties of gases and liquids]. Moscow, Fizmatgiz.

Vtyurin, B.I. 1981. Chto takoye mertvyye l'dy? [What is dead ice?] Materialy Glyatsiologicheskikh Issledovaniy. Khronika. Obsuzhdeniya, Vyp. 40, p. 240-42.

Zotikov, I.A. 1982. Teplofizika lednikovykh pokrovov. [Glacier thermal physics]. Leningrad, Gidrometeoizdat. 